\title{
ДО ПИТАННЯ РЕАЛІЗАЦІЇ ПРАВА НА ЗАБУТТЯ КОРИСТУВАЧАМИ ЦИФРОВИХ СЕРВІСІВ В УКРАЇНI
}

\section{Плескач М. В.}

\section{ВСТУП}

Сучасні інформаційно-комунікаційні та цифрові технології є основною широкого кола можливостей для людини. Вони виступають своєрідним інструментом покращення якості життя, $є$ допоміжними у спрощенні доступу до різноманітних товарів, послуг і сервісів. Також інформаційнокомунікаційні технології дають змогу здійснювати ефективну інтеграцію фізичних, цифрових і людських систем у штучному середовищі заради благополучного та сталого майбутнього людей. Разом із тим першочерговим i важливим $\epsilon$ питання якості таких сервісів, їх відповідність вимогам стандартів у галузі кібернетичної та інформаційної безпеки, а також положенням нормативних документів із питань захисту персональних даних та прав людини загалом.

Цифровим сервісом є ідентифікована вебадресою програмна система зі стандартизованими інтерфейсами. Загалом до вебсервісів належать послуги, що надаються в інтернеті ${ }^{1}$. Відповідно до ДСТУ ISO/IEC 200003:2017 «Інформаційні технології. Керування послугами. Частина 3. Настанова щодо визначення сфери та застосовності ISO/IEC 20000-1» (ISO/IEC 20000-3:2012, IDT), цифровий сервіс - це задоволення потреб споживачів у послугах через інформаційно-комунікаційні технології в розподіленому, обчислювальному середовищі глобальної мережі Інтернет, яким властивий переважно цифровий спосіб подання ${ }^{2}$.

Для України питання безпечності цифрових сервісів набуває дедалі більшої актуальності у зв'язку з невпинним збільшенням їх кількості в різних сферах життєдіяльності та активним використанням багатьма користувачами.

У травні 2020 р. фахівці Організації Об’єднаних Націй у звіті повідомили про те, що через пандемію «інтернет-трафік у світі збільшився утричі»³.

\footnotetext{
${ }^{1}$ Що таке веб-сервіс та їх види? URL: https://2ip.ua/ua/blog/web-services.

2 ДСТУ ISO/IEC 20000-3:2017 Інформаційні технології. Керування послугами. Частина 3. Настанова щодо визначення сфери та застосовності ISO/IEC 20000-1 (ISO/IEC 20000-3:2012, IDT). URL: http://online.budstandart.com/ua/catalog/doc-page.html?id_doc=74969.

3 COVID-19 makes universal digital access and cooperation essential: UN tech agency. URL: https://news.un.org/en/story/2020/05/1063272.
} 
Людство невпинно просувається до інформаційної епохи, в якій економіка та бізнес стають електронними і здійснюються в мережі Інтернет ${ }^{4}$.

3 огляду на це також спостерігається суттєве збільшення ролі цифрових сервісів, зокрема електронної комерції, в тому числі в Україні.

Електронна комерція здійснює суттєвий вплив на всі види економічної діяльності ${ }^{4}$. Нині європейський оборот електронної комерції неухильно зростає, 3 щорічним темпом близько $12-13 \%{ }^{5}$. Згідно 3 даними Eurostat, в Європейському Союзі на сегмент електронної торгівлі припадає понад $15 \%$ усіх роздрібних продажів у сегменті В2С. Центром інтернет-торгівлі в Європі є Великобританія, де обсяг електронної торгівлі у сфері В2С утричі вищий, ніж на другому за величиною ринку - Німеччині 6 .

Для порівняння, в Україні також спостерігається тенденція до збільшення частки цифрових сервісів в економіці. Так, у 2018 р. українці придбали товарів та послуг орієнтовною вартістю 65 млрд грн. При цьому доходи від рекламних кампаній у соціальних мережах, на маркетплейсах і онлайн-ресурсах різних суб'єктів електронної комерції становили 9,5 млрд грн. Своєю чергою поштові оператори сукупно отримали доходів від доставки товарів, замовлених у режимі онлайн, у розмірі 2,6 млрд грн. Вартість онлайн-оплат склала трохи більше як 0,8 млрд грн. Фахівці у 2018 р. здійснювали прогнози щодо щорічного зростання ринку електронної-торгівлі з приростом мінімум $25 \%$ щороку ${ }^{7}$.

Таке значне зростання сегмента електронної торгівлі та інших цифрових сервісів неможливе без збору даних про споживачів, їх уподобання та потреби. Суб'єкти електронної комерції потребують детальної інформації про наявних та потенційних клієнтів із метою впровадження маркетингових дій та для реалізації товарів і послуг. Нині проблемою є те, що в сучасних умовах жорсткої конкуренції інформація про споживачів може збиратися в обхід або всупереч чинному законодавству про захист персональних даних, а різноманітні цифрові сервіси в Україні дедалі більше характеризуються системними порушеннями, зокрема в аспекті неможливості споживачем повноцінно реалізувати право на забуття під час та після використання відповідного цифрового сервісу. Ситуація

\footnotetext{
${ }^{4}$ Плескач В.Л. Електронна комерція : підручник / В.Л. Плескач, Т.Г. Затонацька. Київ : Знання, 2007. $535 \mathrm{c}$.

5 В2C в електронній комерції: Європейський вектор України. URL: http://www.ier.com.ua/ ua/sme_development/Policy_papers_LEV?pid=5529.

6 Дубовик Т.В. Міжнародна електронна торгівля / Т.В. Дубовик, І.В. Гамова. Науковий вісник Ужггородського національного університету. Серія : Міжнародні економічні відносини та світове господарство. 2018. Вип. 17(1). С. 51-55. URL: http://www.visnyk-econom.uzhnu.uz.ua/archive/17_1_ 2018ua/13.pdf.

7 Підсумки і плани: е-commerce України 2018/2019. URL: https://eopac.org.ua/pidsumky-i-plany-ecommerce-ukrayiny-2018-2019/.
} 
ускладнюється ще й тим, що до прикладу, згідно з дослідженням ICO Bench, у 2018 р. світовий прибуток від використання персональних даних сягнув понад 250 млрд доларів, а експерти прогнозують подальше інтенсивне зростання цього ринку ${ }^{8}$

На жаль, ця проблематика не знайшла детального аналізу в науковій літературі, що і зумовлює проведення цього дослідження.

Метою цього дослідження $\epsilon$ аналіз способів покращення механізму реалізації права на забуття користувачами цифрових сервісів в Україні, а також пошук напрямів вдосконалення нормативно-правових актів, які регулюють вказану сферу.

Об'єктом дослідження є механізм реалізації права на забуття користувачами цифрових сервісів в Україні.

\section{1. Концепція «права на забуття»: причини та передумови виникнення}

Дослідження проблем захисту персональних даних висвітлюються у наукових публікаціях І.В. Арістової, О.А. Баранова К.І. Бєлякова, В.М. Брижка, О.В. Довганя, О.А. Заярного, О.О. Золотар, К.С. Мельника, М.В. Різака, Т.Ю. Ткачука та інших учених. Водночас літературні джерела й публікації з теми цього дослідження є нечисленними, тому аналіз способів покращення механізму реалізації права на забуття користувачами цифрових сервісів в Україні $€$ важливим науковим та практичним завданням.

Закон України «Про основні засади забезпечення кібербезпеки України» визначає, що об'єктами кібернетичної безпеки та кіберзахисту $\epsilon$ конституційні права і свободи людини і громадянина ${ }^{9}$. Безпека визнана Конституцією України як одна 3 найвищих соціальних цінностей ${ }^{10}$. Забезпечення безпеки в кібернетичному просторі $\epsilon$ не менш важливим завданням та обов'язком уповноважених суб'єктів іiі забезпечення. На нашу думку, кібернетична безпека може бути виражена через сукупність прав, свобод та інтересів, серед яких вагоме місце посідає право людини на захист персональних даних під час використання кібернетичного простору, а також право на забуття.

Як зазначає П.М. Сухорольський, важливим елементом права на захист персональних даних у деяких правових системах, включаючи правову

\footnotetext{
${ }^{8}$ PDATA. Personal data marketplace powered by blockchain. URL: https://icobench.com/ico/personal-datademocracy.

${ }^{9}$ Про основні засади забезпечення кібербезпеки України : Закон України від 05.10.2017 р. № 2163VIII. Дата оновлення: 08.07.2018. URL: https://zakon.rada.gov.ua/laws/show/2163-19 (дата звернення: 28.05.2020).

10 Конституція України: Закон від 28.06.1996 № 254к/96-ВР. Дата оновлення: 01.01.2020. URL: https://zakon.rada.gov.ua/laws/show/254\%D0\%BA/96-\%D0\%B2\%D1\%80 (дата звернення: 28.05.2020).
} 
систему Європейського Союзу, є право бути забутим, яке передбачає змогу особи вимагати за певних обставин знищення даних про неї, передусім у межах популярних інтернет-ресурсів ${ }^{11}$.

Право на забуття бере початок зі справи «Google Spain SL, Google Inc. v Agencia Española de Protección de Datos, Mario Costeja González» 2014 p., a також відповідного рішення Суду Європейського Союзу, згідно з яким операторів пошукової системи було зобов'язано видаляти зі списку результатів, виданих у відповідь на пошуковий запит на основі імені особи, посилання на вебсторінки, що містять інформацію про цю особу, навіть тоді, коли така інформація була розміщена на законних підставах ${ }^{12}$.

Нині право на забуття закріплюється ст. 17 Загального регламенту захисту даних (General Data Protection Regulation) Європейського Союзу, який змінив способи збору та захисту персональних даних, а також механізми обробки даних клієнтів ${ }^{13}$. Тобто Загальний регламент захисту даних закріплює за людиною право вимагати видалення іï даних, а також відкликати свою згоду на обробку даних. Крім того, після введення в дію Загального регламенту захисту даних «право на забуття» поширилось не лише на пошукові системи щодо видалення інформації з пошуку, а й на видалення інформації про себе з будь-якого сайту.

Однак варто звернути увагу, що право на забуття не $є$ абсолютним ${ }^{14}$ i не може бути реалізовано, якщо: зібрані персональні дані $\epsilon$ необхідними для здійснення права на свободу вираження поглядів; є юридичне зобов'язання зберігати такі дані; персональні дані становлять суспільний інтерес (наприклад, для охорони здоров'я, наукових, статистичних чи історичних цілей дослідження $)^{15}$. Крім того, положення Загального регламенту захисту даних поширюються на тих суб'єктів, які здійснюють свою діяльність, зокрема і в всесвітній мережі Інтернет, на території Європейського Союзу або прямо чи опосередковано мають доступ до персональних даних осіб, що знаходяться на території Європейського Союзу. ${ }^{16}$

\footnotetext{
${ }^{11}$ Сухорольський П. Право бути забутим у правовій системі Європейського Союзу: реалії, проблеми та перспективи. Наука міжнародного права на рубежі століть. Тендениії розвитку та трансформації : спеціальне видання наукових статей. Львів : ЛНУ імені Івана Франка, 2016. С. 90-101. URL: http://ena.lp.edu.ua:8080/bitstream/ntb/34412/1/sukhorolskyi16.pdf.

${ }^{12}$ An internet search engine operator is responsible for the processing that it carries out of personal data which appear on web pages published by third parties. URL: https://curia.europa.eu/jcms/ upload/docs/application/pdf/2014-05/cp140070en.pdf.

${ }_{13}^{13}$ General Data Protection Regulation (GDPR). URL: https://gdpr-info.eu/art-17-gdpr/

${ }^{14}$ Гринишин М. «Право на забуття: міжнародні та національні стандарти». URL: http://law.ucu.edu.ua/marichka-grynyshyn-pravo-na-zabuttya-mizhnarodni-ta-natsionalni-standarty/.

15 Do we always have to delete personal data if a person asks? URL: https://ec.europa.eu/info/law/lawtopic/data-protection/reform/rules-business-and-organisations/dealing-citizens/do-we-always-have-deletepersonal-data-if-person-asks_en.

16 Гук I. Право на забуття: що варто знати. URL: https://protocol.ua/ru/pravo_na_zabuttya_ shcho_varto_znati/.
} 
Нині українські цифрові сервіси (зокрема, електронної пошти, сайти електронної комерції (інтернет-магазини), електронні засоби масової інформації тощо), які не обробляють персональні дані резидентів Європейського Союзу, не підпадають під дію норм Загального регламенту захисту даних, однак у перспективі членства в Свропейському Союзі Україна має прагнути до узгодження законодавства у сфері захисту персональних даних із вимогами Загального регламенту захисту даних.

\section{2. Проблеми реалізації права на забуття при використанні сайтів електронної комерції (інтернет-магазинів)}

Закон України «Про електронну комерцію» визначає, що електронною комерцією є відносини, спрямовані на отримання прибутку, що виникають під час вчинення правочинів щодо набуття, зміни або припинення цивільних прав та обов'язків, здійснені дистанційно 3 використанням інформаційно-телекомунікаційних систем, внаслідок чого в учасників таких відносин виникають права та обов'язки майнового характеру.

Під електронною торгівлею розуміється господарська діяльність у сфері електронної купівлі-продажу, реалізації товарів дистанційним способом покупцю шляхом вчинення електронних правочинів із використанням інформаційно-телекомунікаційних систем.

Своєю чергою, інтернет-магазин визначається як засіб для представлення або реалізації товару, роботи чи послуги шляхом вчинення електронного правочину ${ }^{17}$.

Як зазначалось, підприємницька діяльність в Україні, яка так чи інакше пов'язана з обробкою персональних даних, із кожним роком зростає.

Суб' єкти підприємницької діяльності систематично збирають персональні дані для власних потреб, зокрема для покращення роботи клієнтів, поповнення клієнтської бази, аналізу і запам'ятовування потреб і уподобань, маркетингу тощо. На думку О.А. Заярного, саме цей вид інформації безпосередньо вноситься власниками, розробниками чи споживачами Інтернету речей із метою їх подальшого використання, вилучення необхідної користі від їх експлуатації, ідентифікації та авторизації в системі, визначення власних потреб, що підлягають задоволенню тощо ${ }^{18}$.

\footnotetext{
${ }^{17}$ Про електронну комерцію : Закон України від 03.09.2015 р. № 675-VIII. Дата оновлення: 19.04.2020. URL: https://zakon.rada.gov.ua/laws/show/675-19 (дата звернення: 28.05.2020).

18 Заярний О.А. Деякі проблеми правового забезпечення правомірної обробки біометричних персональних даних у процесі використання інтернету речей. Матеріали другої наук.-практ. конф., 29 лист. 2018 р., м. Київ / Упоряд. : В.М. Фурашев, С.О. Дорогих. Київ : КПІ ім. Ігоря Сікорського, Видво «Політехніка», 2018. 168 с. URL: http://ipp.kpi.ua/\%D1\%96\%D0\%BD\%D1\%82\%D0\%B5\%D1\%80\% D0\%BD\%D0\%B5\%D1\%82-\%D1\%80\%D0\%B5\%D1\%87\%D0\%B5\%D0\%B9-\%D0\%BF\%D1\%80\%D0\% BE\%D0\%B1\%D0\%BB\%D0\%B5\%D0\%BC\%D0\%B8-\%D0\%BF\%D1\%80\%D0\%B0\%D0\%B2\%D0\%BE\% D0\%B2\%D0\%BE\%D0\%B3\%D0\%BE-\%D1\%80\%D0\%B5/.
} 
При цьому законодавство України у сфері захисту персональних даних містить прогалини та потребує вдосконалення. Наприклад, Закон України «Про захист персональних даних», а саме ст. 15, регулює порядок видалення або знищення персональних даних. А ч. 2 ст. 8 цього Закону України визначає права суб'єкта персональних даних, серед яких $є$ право пред'являти вмотивовану вимогу щодо зміни або знищення своїх персональних даних будь-яким володільцем та розпорядником персональних даних, якщо ці дані обробляються незаконно чи $\epsilon$ недостовірними ${ }^{19}$. Тобто ця норма не поширюється на випадки, якщо відповідні дані обробляються на законних підставах. Однак право бути забутим охоплює і ті випадки, коли дані обробляються без порушення законодавства ${ }^{11}$.

Крім того, чинне законодавство України, на відміну від Загального регламенту захисту даних, не містить обов'язкового положення, що процедура відкликання згоди на обробку персональних даних має бути такою ж простою, як і ії отримання. Також відсутніми є обов'язкові вимоги до функціонування вебсайтів відповідних цифрових сервісів, зокрема в аспекті передбачення технічної змоги користувача видалити персональні дані про себе та самостійно управляти особистим кабінетом (профілем).

Так, для прикладу, нами було проаналізовано структуру деяких інтернет-магазинів, які найчастіше відвідують українці ${ }^{20}$ зокрема Kasta.ua, ${ }^{21}$ і було виявлено:

1) процедура відкликання згоди на обробку персональних даних $\epsilon$ набагато складнішою, ніж iї отримання. Наприклад, для того, аби зареєструвати свій профіль, достатньо ввести номер телефону користувача, а також код із смс-повідомлення щодо підтвердження реєстрації. При цьому обов'язкова відмітка про те, що користувач ознайомився 3 Політикою конфіденційності, відсутня. На сайті Kasta.ua наявна лише інформація про те, що після введення електронної адреси чи номеру телефону, користувач автоматично погоджується 3 умовами Угоди користувача. При цьому, відповідно до п. 14.4 Угоди користувача, якщо покупець із будь-якої причини бажає припинити покупки і видалити свій профіль, йому необхідно звернутися з цим питанням до служби підтримки;

2) неможливість проконтролювати дії володільців/розпорядників персональних даних навіть після відкликання згоди на обробку персональних даних чи після видалення профілю, що унеможливлює

\footnotetext{
${ }^{19}$ Про захист персональних даних : Закон України від 01.06.2010 р. № 2297-VI. Дата оновлення: 20.03.2020. URL: https://zakon.rada.gov.ua/laws/show/2297-17 (дата звернення: 28.05.2020).

20 К. Коцан. URL: Які інтернет-магазини є найпопулярнішими серед українців: рейтинг. https://shotam.info/yaki-internet-mahazyny-ie-naypopuliarnishymy-sered-ukraintsiv-reytynh/.

${ }^{21}$ Kasta.ua. URL: https://kasta.ua/page/support/agreement/
} 
отримання достовірної інформації користувачем про подальшу юридичну долю персональних даних;

3) відповідно до п. 1.8. Угоди користувача, покупець, протягом усього строку здійснення покупок на онлайн-майданчику Kasta.ua (використання Сайту та/або мобільного додатку), має право змінювати та доповнювати надані ним дані. Однак положення про те, що покупець може самостійно видаляти надані ним дані, відсутнє;

4) відповідно до п. 13.2 Угоди користувача, адміністратор має право на обробку персональних даних покупців - будь-яку дію або сукупність дій, таких як збирання, реєстрація, накопичення, зберігання, адаптування, зміна, поновлення, використання і поширення (поширення, реалізація, передача), знеособлення, знищення персональних даних, у тому числі 3 використанням інформаційних (автоматизованих) систем.

Варто зазначити, що ст. 2 Закону України «Про захист персональних даних» визначає, що у сфері електронної комерції згода суб'єкта персональних даних може бути надана під час реєстрації в інформаційнотелекомунікаційній системі суб’єкта електронної комерції шляхом проставлення відмітки про надання дозволу на обробку персональних даних відповідно до сформульованої мети їх обробки ${ }^{19}$. Однак сайт Kasta.ua не містить чітко визначеної мети обробки персональних даних. А формулювання «збирання, реєстрація, накопичення, зберігання, адаптування, зміна, поновлення, використання i поширення (розповсюдження, реалізація, передача), знеособлення, знищення персональних даних», на нашу думку, суперечить загальним вимогам до обробки персональних даних, зокрема ч. 3 та ч. 5 ст. 6 Закону України «Про захист персональних даних», згідно з якими склад та зміст персональних даних мають бути відповідними, адекватними та ненадмірними стосовно визначеної мети їх обробки; а обробка персональних даних має здійснюватися для конкретних і законних цілей, визначених за згодою суб'єкта персональних даних.

Особливе занепокоєння викликає наявність такого поняття, як «інформаційна взаємодія щодо передавання персональних даних, які реалізовуються за допомогою угод між компаніями» ${ }^{22}$.

Ще одним прикладом неможливості повноцінно реалізувати право на забуття $\epsilon$ порядок роботи в інтернет-магазині Makeup.ua ${ }^{23}$. Так, нами було виявлено, що:

1) реєстрація особистого кабінету є досить простою ${ }^{24}$. Достатньо вказати особисті дані клієнта, натиснути кнопку «Зареєструватися», після чого

\footnotetext{
22 Персональні дані «валюта 21 століття»: хто продає, а хто купує? URL: https://ecpl.com.ua/news/personal-ni-dani-valiuta-21-stolittia-khto-prodaie-a-khto-kupuie/

${ }^{23}$ Makeup.com.ua. URL: https://makeup.com.ua/ua/about/13/
} 
отримати інформацію з підтвердженням реєстрації на електронну адресу, вказану під час реєстрації. Будь-які попередження чи нагадування про необхідність ознайомитися 3 Політикою конфіденційності, Умовами користування інтернет-магазином тощо відсутні. Варто зазначити, що обов'язок із пошуку Умов використання вказаного інтернет-магазину покладається на самого користувача. При цьому положення ст. 2 Закону України «Про захист персональних даних», а саме те, що у сфері електронної комерції згода суб'єкта персональних даних може бути надана під час реєстрації в інформаційно-телекомунікаційній системі суб'єкта електронної комерції шляхом проставлення відмітки про надання дозволу на обробку своїх персональних даних відповідно до сформульованої мети їх обробки, за умови, що така система не створює можливостей для обробки персональних даних до моменту проставлення відмітки, цим інтернет-магазином ігнорується;

2) відповідно до п. 3.4. Умов використання сайту, покупець дає право Адміністрації здійснювати обробку його персональних даних, зокрема поміщати персональні дані в бази даних Адміністрації (без додаткового повідомлення про це), здійснювати довічне зберігання даних, їx накопичення, оновлення, зміну (за потреби). У зв'язку з цим виникає питання, чи $є$ доцільність у довічному зберіганні даних споживача (покупця) $\mathrm{i}$ чи не $\epsilon$ це порушенням загальних вимог до обробки персональних даних, зокрема щодо ненадмірності, встановлених ст. 6 Закону України «Про захист персональних даних»;

3) технічні можливості для видалення особистого кабінету відсутні не лише для споживача (покупця), але і для Адміністратора. Крім того, порядок видалення особистого кабінету Умовами використання сайту не передбачений взагалі. На телефонний запит щодо видалення даних профілю адміністратори пропонують лише редагування особистих даних або змогу вказати недостовірні дані, щоб у подальшому перестати бути клієнтом цього цифрового сервісу. Крім того, дані про здійснені покупки також видалити неможливо. Така ситуація спричиняє перешкоди не лише для реалізації права на забуття, а й може бути порушенням п.п. 2 ч. 2 ст. 15 Закону України «Про захист персональних даних», згідно 3 якою персональні дані підлягають видаленню або знищенню в разі припинення правовідносин між суб'єктом персональних даних та володільцем чи розпорядником, якщо інше не передбачено законом.

24 Makeup.com.ua. URL: https://makeup.com.ua/ua/register/?_cf_chl_jschl_tk_=6d9d5e11147d 25 20c36c87f8fc6a1389f915da76-1590134967-0-AZ9GHHN-DCN4rkq80azltAymWiav64Sm24STbr7ckRMo EoVYDoLPIKxRn0J5_R8EyaHZJNgdBADBXEk1JvGA89RkpIW4xKpd7L4GtBFdu_dLuqcK_qlSENZETGH YK_ioQa-gd32AOzm1 fz80HrFNziPpIeoNFLCXtq8FOIYiEHIiApjW_UyQr5jk-zU4gUmcrnvIBiZ7fLHwu MlrdangwVOoe-za-1NjObYE2HaV9tOrY6rdjdF6DIy25yDtwvnq-NAwLWR4aIQYWbYMXf_un3uFwkVy D5m3oVY46nwi6Y 
Для порівняння доречно звернути увагу на ту обставину, що у версії інтернет-магазину Makeup.ua, орієнтованого на споживачів Свропейського Союзу (наприклад, Польща), чітко регламентовано необхідність прийняття умов, визначених Загальним регламентом захисту даних та Політикою конфіденційності (знімок екрана, рис. 1).

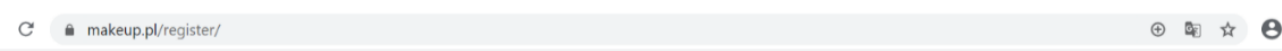

Rejestracja nowego użytkownika

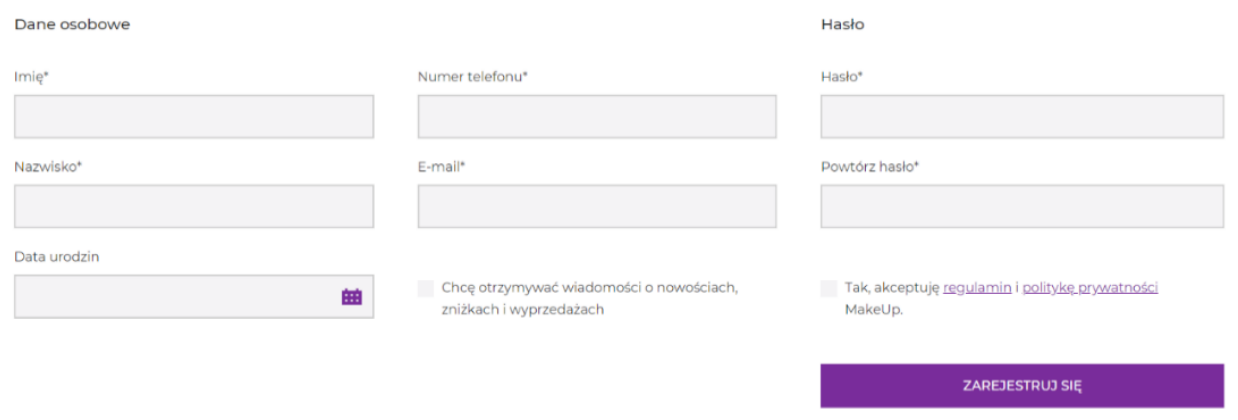

Рис. 1

Своєю чергою український інтернет-магазин Makeup.ua вимоги щодо попередження українського споживача про Політику конфіденційності та Умови використання персональних даних ігнорує (знімок екрана, рис. 2).

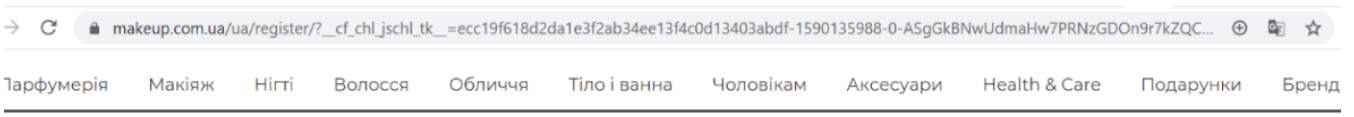

Реєстрація нового користувача

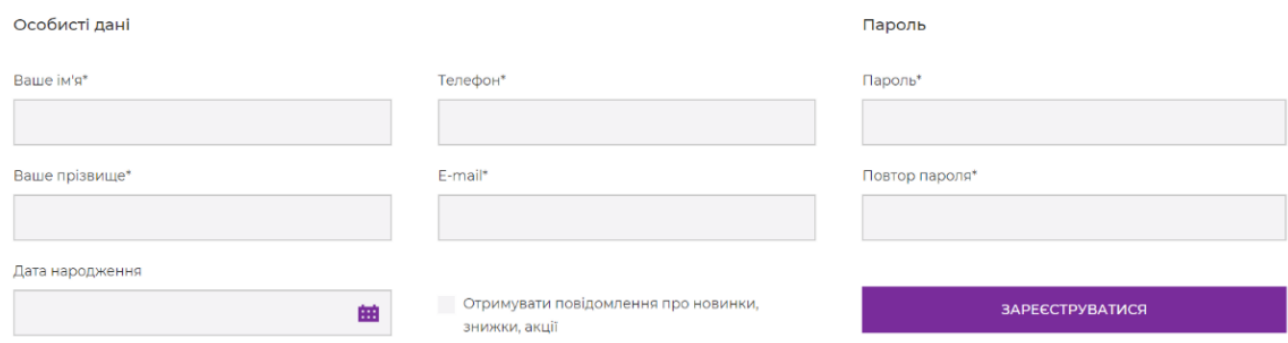

Pис. 2 
Варто зазначити, що вищезазначеними прикладами не обмежується порушення права на забуття українськими інтернет-магазинами. Зважаючи на неможливість детального вивчення усього сегменту електронної комерції, ми для потреб цього дослідження вибірково вибрали деякі інтернет-магазини, які $є$ найбільш затребуваними серед українців.

\section{3. Проблеми реалізації права на забуття при використанні вебсайтів грального бізнесу (парі, тоталізаторів та інших азартних ігор)}

На окрему увагу нині заслуговує діяльність вебсайтів лотерей, які за своєю суттю в Україні підпадають під ознаки грального бізнесу, парі, тоталізаторів чи інших азартних ігор. Передусім доречно зазначити, що фахівцями справжні доходи від ринку азартних ігор оцінюються у 40 млрд грн $^{25}$. Такий рівень доходів може свідчити про високу популярність серед українців азартних ігор.

Так, згідно $з$ результатами опитування, проведеного «Українською національною лотереєю», більше половини опитаних респондентів не цікавляться азартними іграми (близько 51\%). Орієнтовно 4\% українців визнали, що грають на гроші постійно, 10\% іноді грають в азартні ігри, така сама кількість респондентів сказала, що вороже ставиться до такого заняття і засуджує гравців.

Серед тих, хто грає в азартні ігри, майже половина (45\%) віддає перевагу лотереям. Букмекерські ставки і ставки на спорт робить майже кожен п'ятий «гравець» (19\%), ще 17\% зізнаються, що грають на гроші, зокрема в казино, 16\% грають на автоматах. Три чверті опитаних віддають перевагу наземним точкам продажу лотерей, а в інтернеті грає $15 \%{ }^{26}$.

З 2009 р. в Україні діє заборона цієї сфери діяльності, однак на практиці цей бізнес працює в тіні.

Навіть після масового закриття правоохоронними органами гральних закладів, що видавали себе за лотереї, доступ населення до них залишається, передусім в онлайн-формі. Так, для прикладу, попри рішення Печерського районного суду Києва, який зобов'язав інтернет-провайдерів, що працюють в Україні, заблокувати доступ до 60 вебсайтів, серед яких 47 сайтів онлайн-казино i букмекерських контор, зокрема «Фаворит спорт», Parimatch та «Космолот» ${ }^{27}$, вказані ресурси продовжують успішно

\footnotetext{
25 Кому принадлежат лотереи и букмекерские конторы в Украине. URL: https:// dengi.informator.ua/2019/01/11/komu-prinadlezhat-loterei-i-bukmekerskie-kontory-v-ukraine/

26 Скільки українців грають в азартні ігри: промовиста статистика. URL: https://24tv.ua/ skilki_ukrayintsiv_grayut_v_azartni_igri_promovista_statistika_n1030643

${ }^{27}$ Суд заблокував сайти найбільших українських онлайн-казино та букмекерів https://zaxid.net/news/. URL: https://zaxid.net/sud_zablokuvav_mayzhe_50_saytiv_onlayn_kazino_ta_bukmekerskih_kontor_v_ ukrayini_n1497568
} 
функціонувати, пропонувати свої послуги та збирати персональні дані своїх користувачів.

Як вже зазначалось, у сфері електронної комерції згода суб'єкта персональних даних може бути надана під час реєстрації в інформаційнотелекомунікаційній системі суб'єкта електронної комерції шляхом проставлення відмітки про надання дозволу на обробку своїх персональних даних відповідно до сформульованої мети їх обробки, за умови, що така система не створює можливостей для обробки персональних даних до моменту проставлення відмітки. Однак це положення нині не поширюється на правочини, якщо вони стосуються грального бізнесу, в тому числі парі, тоталізатори та інші азартні ігри, або проведення лотерей, що фактично послаблює контроль за захистом персональних даних у цій сфері.

Аналіз умов та правил користування вебсайтом kosmolotonline.com ${ }^{28}$ дає також підстави твердити про їх несправедливість та недотримання принципу рівності учасників правовідносин. Зокрема, відповідно до п. 30.3 умов та правил користування вебсайтом kosmolotonline.com, якщо користувач бажає переглянути будь-яку персональну інформацію, яку адміністратор вказаного сайту зберігає про нього або якщо користувач хоче внести зміни у персональні дані або видалити їх, він має подати адміністратору відповідний запит. Такий запит має бути поданий у письмовому вигляді, а також має містити ім'я, адресу і опис інформації, 3 якою користувач бажає ознайомитися/виправити або видалити. Також запит може бути поданий за електронною адресою або поштою. При цьому 3 метою дотримання конфіденційності, під час подачі запиту, також необхідно подати підтвердження, що ідентифікує особу користувача, а також необхідно додати до звернення копію усього паспорта ${ }^{29}$. При цьому реєстрацію на вказаному сайті пропонується здійснити лише за 10 секунд, що не передбачає ознайомлення користувача з Політикою конфіденційності та умовами користування вебсайтом (знімок екрана, рис. 3).

На нашу думку, такі непропорційні вимоги щодо порядку видалення персональних даних користувача явно не можуть вважатися дотриманням принципів обробки персональних даних, встановлених чинним законодавством про захист персональних даних.

Ми можемо погодитись із тезою про те, що людина є метою і критерієм цивілізаційного прогресу і не може бути елементом мережевої організації в суспільстві мережевих структур, а тільки має взаємодіяти 3 мережевими інституціями опосередковано через певні механізми і за власним бажанням ${ }^{4}$.

\footnotetext{
${ }^{28}$ Kosmolotonline.com. URL: https://kosmolotonline.com/\#

${ }^{29}$ Kosmolotonline.com. URL: https://kosmolotonline.com/rules\#
} 
Проведений нами аналіз низки цифрових сервісів в Україні дає підстави стверджувати про повну чи часткову неможливість повноцінно реалізувати право на забуття, а також відкликати надану згоду на обробку персональних даних. Несправедливі умови користування цифровими сервісами, які передбачають, що відкликання згоди на обробку персональних даних не $\epsilon$ таким же простим, як і іiі надання, призводить до того, що споживач перестає бути повноцінним учасником вказаних правовідносин, що своєю чергою ставить його у нерівне становище із суб'єктом, який $\epsilon$ адміністратором (власником) відповідного цифрового сервісу.

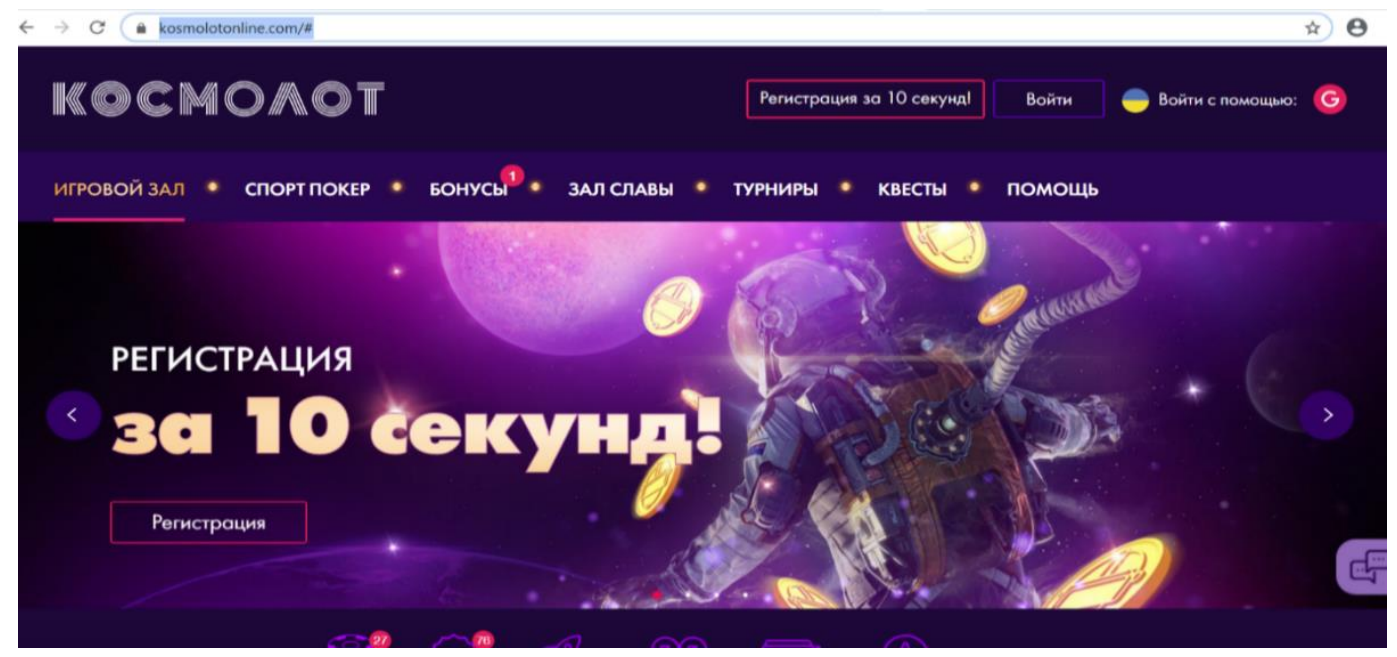

Pис. 3

У зв'язку з цим, коли людина реєструється на певному цифровому сервісі, надаючи суб'єкту підприємницької діяльності персональні дані, вона не має бути обмежена у праві відкликати згоду на обробку персональних даних без зайвих процедур та самостійно видалити дані про себе.

Як слушно зазначає К.С. Мельник, нині питання захисту персональних даних викликає занепокоєння у значної кількості людей в Україні через незаконне поширення, несанкціоноване використання персональних даних. Цей дослідник акцентує на тому, що, попри наявний правовий механізм захисту персональних даних, на практиці він $є$ досить складним у реалізації, з об'єктивних та суб'єктивних причин, зокрема через труднощі політичної та соціально-економічної реформації, яка триває в Україні досить повільно ${ }^{30}$.

\footnotetext{
${ }^{30}$ Мельник К.С. Удосконалення нормативно-правового регулювання захисту персональних даних в Україні. Правова інформатика. 2014. № 1. С. 30-43. URL: http://nbuv.gov.ua/UJRN/Pinform_2014_1_7.
} 


\section{ВИСНОВКИ}

1. Нереформованість українського законодавства у сфері захисту персональних даних призводить до панування формального підходу щодо його дотримання суб'єктами електронної комерції та інших цифрових сервісів. Через відсутність у нормативно-правових актах України обов'язкового положення, що процедура відкликання згоди на обробку персональних даних має бути такою ж простою, як і іiі отримання, користувач деяких цифрових сервісів позбавлений права видалити персональні дані про себе та самостійного управляти особистим кабінетом (профілем). У зв'язку з цим, на нашу думку, потребує імплементації норма, що будь-який цифровий сервіс (незалежно від виду: інтернет-магазин, електронна пошта, вебсайт грального бізнесу тощо) має обов'язково містити технічну можливість користувача у будь-який момент видаляти особистий кабінет, профіль чи відкликати згоду на обробку персональних даних.

2. Необхідно передбачити у чинному законодавстві норму, що користувач не може почати роботу з цифровим сервісом без належного ознайомлення 3 Умовами користування сайтом та Політикою конфіденційності, які своєю чергою мають відповідати загальним правилам обробки персональних даних. Передусім потребує вирішення проблема юридичних колізій, а саме недостатньої системності нормативно-правових актів у цій сфері, що полягає в непослідовності викладення деяких норм. Зокрема, відповідно до ч. 3 ст. 14 Закону України «Про електронну комерцію», реєстрація фізичної особи в інформаційній системі суб'єкта електронної комерції означає надання нею згоди на використання та обробку iі персональних даних і вчинення інших дій, передбачених Законом України «Про захист персональних даних». Тобто реєстрація користувача в певній системі передбачає автоматичне надання ним згоди на обробку персональних даних, навіть без проставлення відмітки про те, що він надає таку згоду. Водночас, відповідно до ст.2 Закону України «Про захист персональних даних», у сфері електронної комерції згода суб'єкта персональних даних може бути надана під час реєстрації в інформаційнотелекомунікаційній системі суб'єкта електронної комерції шляхом проставлення відмітки про надання дозволу на обробку своїх персональних даних відповідно до сформульованої мети їх обробки, за умови, що така система не створює можливостей для обробки персональних даних до моменту проставлення відмітки. Тобто ст. 14 Закону України «Про електронну комерцію» потребує узгодження із профільним Законом України «Про захист персональних даних» 3 метою приведення діяльності цифрових сервісів до законодавства, що регулює захист персональних 
даних і зменшення випадків порушення інформаційних прав користувачів таких сервісів.

3. Нині необхідним також є внесення змін до профільних нормативноправових актів України щодо посилення відповідальності за порушення законодавства про захист персональних даних, зокрема потребує адаптації законодавство України до законодавства Європейського Союзу, яке закріплює механізм реалізації та захисту права на забуття користувачами цифрових сервісів.

При цьому можемо погодитись із думкою М.В. Різака, який вважає, що, удосконалюючи вітчизняне законодавство, варто запроваджувати не фіксовані штрафні санкції, а стягнення у відсотках із доходу, розмір якого залежить від ступеня тяжкості правопорушення та інших обставин, помножений на проміжок часу, коли тривало порушення законодавства у сфері захисту персональних даних. Запровадження таких санкцій може стати ефективним інструментом гарантування безпеки персональних даних ${ }^{31}$.

4. Також не менш важливим напрямом вдосконалення механізму реалізації права на забуття могло би стати створення репутаційного реєстру цифрових сервісів, які дотримуються чи не дотримуються вимог із захисту персональних даних, у тому числі щодо реалізації права на забуття. Оскільки репутація компанії за останні роки набула монетарного статусу і за різними оцінками становить до $60 \%$ вартості компаній ${ }^{32}$. Вказаний напрям діяльності уповноважених суб'єктів міг би також допомогти в досягненні належного рівня культури відносин, у тому числі інформаційних ${ }^{33}$.

\section{АНОТАЦІЯ}

Це дослідження присвячене аналізу способів покращення механізму реалізації права на забуття користувачами цифрових сервісів в Україні. У публікації аналізуються деякі напрями вдосконалення нормативноправових актів, які регулюють зазначену сферу. Також ця публікація містить дослідження структури найбільш використовуваних цифрових сервісів в Україні на відповідність їх чинному законодавству, що регулює захист персональних даних в Україні, а також функціональної можливості реалізації користувачем права на забуття.

\footnotetext{
${ }^{31}$ Різак М. Практика країн Європейського Союзу та України у сфері судочинства щодо гарантування безпеки обігу та обробки персональних даних. Підприємницчвво, господарство $і$ право. 2017. № 7 . C. 68-72. URL: http://nbuv.gov.ua/UJRN/Pgip_2017_7_14

32 Як вимірювати ефективність PR? URL: http://www.management.com.ua/blog/247

${ }^{33}$ Ткачук Т.Ю. Монографія. Київ : ТОВ «Видавничий дім «АртЕк», 2018. 411 c. URL: http://ippi.org.ua/ zabezpechennya-informatsiinoi-bezpeki-v-umovakh-\%D1\%94vrointegratsii-ukraini-pravovii-vimir
} 
Проведене дослідження ряду цифрових сервісів в Україні дає підстави стверджувати про повну чи часткову неможливість повноцінно реалізувати право на забуття, а також відкликати надану згоду на обробку персональних даних. Несправедливі умови користування цифровими сервісами, які передбачають, що відкликання згоди на обробку персональних даних не є таким же простим, як і ії надання, призводить до того, що споживач перестає бути повноцінним учасником правовідносин, що своєю чергою ставить його в нерівне становище порівняно із суб'єктом, який $\epsilon$ адміністратором (власником) відповідного цифрового сервісу.

Висновки дослідження можуть бути використані в подальшій науковій i правозастосовній діяльності, спрямованій на покращення механізму реалізації права на забуття користувачами цифрових сервісів в Україні.

\section{ЛІТЕРАТУРА}

1. Що таке веб-сервіс та їх види? URL: https://2ip.ua/ua/blog/web-services.

2. ДСТУ ISO/IEC 20000-3:2017 Інформаційні технології. Керування послугами. Частина 3. Настанова щодо визначення сфери та застосовності ISO/IEC 20000-1 (ISO/IEC 20000-3:2012, IDT). URL: http:// online.budstandart.com/ua/catalog/doc-page.html?id_doc=74969.

3. COVID-19 makes universal digital access and cooperation essential: UN tech agency. URL: https://news.un.org/en/story/2020/05/1063272.

4. Плескач В.Л. Електронна комерція : підручник / В.Л. Плескач, Т.Г. Затонацька. Київ : Знання, 2007. 535 с.

5. B2C в електронній комерції: Європейський вектор України. URL: http://www.ier.com.ua/ua/sme_development/Policy_papers_LEV?pid=5529.

6. Дубовик Т.В. Міжнародна електронна торгівля / Т.В. Дубовик, І.В. Гамова. Науковий вісник Уэггородського національного університету. Серія : Міжнародні економічні відносини та світове господарство. 2018. Вип. 17(1). С. 51-55. URL: http://www.visnyk-econom.uzhnu.uz.ua/archive/ 17_1_2018ua/13.pdf.

7. Підсумки i плани: e-commerce України 2018/2019. URL: https://eopac.org.ua/pidsumky-i-plany-e-commerce-ukrayiny-2018-2019/.

8. PDATA. Personal data marketplace powered by blockchain. URL: https://icobench.com/ico/personal-data-democracy.

9. Про основні засади забезпечення кібербезпеки України : Закон України від 05.10.2017 р. № 2163-VIII. Дата оновлення: 08.07.2018. URL: https://zakon.rada.gov.ua/laws/show/2163-19 (дата звернення: 28.05.2020).

10. Конституція України: Закон від 28.06.1996 № 254к/96-ВР. Дата оновлення: 01.01.2020. URL: https://zakon.rada.gov.ua/laws/show/254\%D0\% BA/96-\%D0\%B2\%D1\%80 (дата звернення: 28.05.2020). 
11. Сухорольський П. Право бути забутим у правовій системі Європейського Союзу: реалії, проблеми та перспективи. Наука міжнародного права на рубежі століть. Тенденції розвитку та трансформації : спеціальне видання наукових статей. Львів : ЛНУ імені Івана Франка, 2016. C. 90-101. URL: http://ena.lp.edu.ua:8080/bitstream/ ntb/34412/1/sukhorolskyi16.pdf.

12. An internet search engine operator is responsible for the processing that it carries out of personal data which appear on web pages published by third parties. URL: https://curia.europa.eu/jcms/upload/docs/application/pdf/201405/cp140070en.pdf.

13. General Data Protection Regulation (GDPR). URL: https://gdpr-info.eu/ art-17-gdpr/.

14. Гринишин М. «Право на забуття: міжнародні та національні стандарти». URL: http://law.ucu.edu.ua/marichka-grynyshyn-pravo-nazabuttya-mizhnarodni-ta-natsionalni-standarty/.

15. Do we always have to delete personal data if a person asks? URL: https://ec.europa.eu/info/law/law-topic/data-protection/reform/rules-businessand-organisations/dealing-citizens/do-we-always-have-delete-personal-data-ifperson-asks_en.

16. Гук I. Право на забуття: що варто знати. URL: https://protocol.ua/ ru/pravo_na_zabuttya_shcho_varto_znati/.

17. Про електронну комерцію : Закон України від 03.09.2015 р. № 675VIII. Дата оновлення: 19.04.2020. URL: https://zakon.rada.gov.ua/laws/show/ 675-19 (дата звернення: 28.05.2020).

18. Заярний О.А. Деякі проблеми правового забезпечення правомірної обробки біометричних персональних даних у процесі використання інтернету речей. Матеріали другої наук.-практ. конф., 29 лист. 2018 р., м. Київ / Упоряд. : В.М. Фурашев, С.О. Дорогих. Київ : КПІ ім. Ігоря Сікорського, Вид-во «Політехніка», 2018. 168 c. URL: http://ipp.kpi.ua/ $\% \mathrm{D} 1 \% 96 \% \mathrm{D} 0 \% \mathrm{BD} \% \mathrm{D} 1 \% 82 \% \mathrm{D} 0 \% \mathrm{~B} 5 \% \mathrm{D} 1 \% 80 \% \mathrm{D} 0 \% \mathrm{BD} \% \mathrm{D} 0 \% \mathrm{~B} 5 \% \mathrm{D} 1 \% 82$ -\%D1\%80\%D0\%B5\%D1\%87\%D0\%B5\%D0\%B9-\%D0\%BF\%D1\%80\%D0\% BE\%D0\%B1\%D0\%BB\%D0\%B5\%D0\%BC\%D0\%B8-\%D0\%BF\%D1\%80\% D0\%B0\%D0\%B2\%D0\%BE\%D0\%B2\%D0\%BE\%D0\%B3\%D0\%BE-\%D1\% $80 \% \mathrm{D} 0 \% \mathrm{~B} 5 /$.

19. Про захист персональних даних : Закон України від 01.06.2010 p. № 2297-VI. Дата оновлення: 20.03.2020. URL: https://zakon.rada.gov.ua/ laws/show/2297-17 (дата звернення: 28.05.2020).

20. Коцан K. URL: Які інтернет-магазини $\epsilon$ найпопулярнішими серед українців: рейтинг. URL: https://shotam.info/yaki-internet-mahazyny-ienaypopuliarnishymy-sered-ukraintsiv-reytynh/.

21. Kasta.ua. URL: https://kasta.ua/page/support/agreement/. 
22. Персональні дані «валюта 21 століття»: хто продає, а хто купує? URL: https://ecpl.com.ua/news/personal-ni-dani-valiuta-21-stolittia-khto-prodaiea-khto-kupuie/.

23. Makeup.com.ua. URL: https://makeup.com.ua/ua/about/13/.

24. Makeup.com.ua. URL: https://makeup.com.ua/ua/register/?_cf_chl_ jschl_tk_=6d9d5e11147d2520c36c87f8fc6a1389f915da76-1590134967-0AZ9GHHN-_DCN4rkq80azltAymWiav64Sm24STbr7ckRMoEoVYDoLPIKx Rn0J5_R8EyaHZJNgdBADBXEk1JvGA89RkpIW4xKpd7L4GtBFdu_dLuqcK _qlSENZETGHYK__ioQa-gd32AOzm1fz80HrFNziPpIeoNFLCXtq8FOIYiE HIiApjW_UyQr5jk-zU4gUmcrnvIBiZ7fLHwuMlrdangwVOoe-za-1NjObYE2 HaV9tOrY6rdjdF6DIy25yDtwvnq-NAwLWR4aIQYWbYMXf_un3uFwkVyD 5m3oVY46nwi6Y.

25. Кому принадлежат лотереи и букмекерские конторы в Украине. URL: $\quad$ https://dengi.informator.ua/2019/01/11/komu-prinadlezhat-loterei-ibukmekerskie-kontory-v-ukraine/.

26. Скільки українців грають в азартні ігри: промовиста статистика. URL: https://24tv.ua/skilki_ukrayintsiv_grayut_v_azartni_igri_promovista_ statistika_n1030643.

27. Суд заблокував сайти найбільших українських онлайн-казино та букмекерів. URL: https://zaxid.net/sud_zablokuvav_mayzhe_50_saytiv_ onlayn_kazino_ta_bukmekerskih_kontor_v_ukrayini_n1497568.

28. Kosmolotonline.com. URL: https://kosmolotonline.com/\#

29. Kosmolotonline.com. URL: https://kosmolotonline.com/rules\#

30. Мельник К.С. Удосконалення нормативно-правового регулювання захисту персональних даних в Україні. Правова інформатика. 2014. № 1. C. 30-43. URL: http://nbuv.gov.ua/UJRN/Pinform_2014_1_7.

31. Різак М. Практика країн Європейського Союзу та України у сфері судочинства щодо гарантування безпеки обігу та обробки персональних даних. Підприємниџтво, господарство і право. 2017. № 7. С. 68-72. URL: http://nbuv.gov.ua/UJRN/Pgip_2017_7_14.

32. Як вимірювати ефективність PR? URL: http://www.management. com.ua/blog/247.

33. Ткачук Т.Ю. Монографія. Київ : ТОВ «Видавничий дім «АртЕк», 2018. 411 c. URL: http://ippi.org.ua/zabezpechennya-informatsiinoi-bezpeki-vumovakh-\%D1\%94vrointegratsii-ukraini-pravovii-vimir.

\section{Information about author:} Pleskach M. V.,

PhD Student of the Department of Administrative Law Taras Shevchenko National University of Kyiv 60, Volodymyrska str., Kyiv, 01033, Ukraine 